\title{
Hepatitis B and delta virus infection among "at risk" populations in south east London
}

\author{
H M Smith, G J M Alexander, G Webb, T McManus, I G McFarlane, Roger Williams
}

\begin{abstract}
Study objective-The hepatitis delta virus (HDV) contributes significantly to the morbidity and mortality of hepatitis $B$ virus (HBV) infection, which is particularly prevalent among intravenous drug users and male homosexuals. A recent report has indicated that HDV first appeared in the South East London intravenous drug using population in 1982 . The aim of the present study was to assess the prevalence of $\mathrm{HDV}$ in these two groups at risk of $\mathrm{HBV}$ infection in South East London.
\end{abstract}

Design-The study was a cohort analysis of $\mathrm{HBV}$ and delta virus serum markers, stratified temporally and with respect to intravenous drug use and sexual practice.

Setting-This was a population study of 372 consecutive intravenous drug users attending a local drug rehabilitation centre and 1481 subjects seen at a sexually transmitted disease clinic in the same area, during the years 1979 to 1988 .

Measurements and main results-Of 372 intravenous drug users, $195(52.4 \%)$ had evidence of current or past infection with HBV, of whom 17 had chronic HBV infection-a carriage rate of $8 \cdot 7 \%$. Twelve $(70.6 \%)$ of these 17 also had chronic HDV infection-the first cases being identified in 1984. By comparison, $406(27 \cdot 4 \%)$ of the sexually transmitted disease clinic patients had been been exposed to HBV, 32 having chronic HBV-a carriage rate of $7.9 \%(7.5 \%$ $v \mathbf{9 . 4 \%}$ among male homosexuals $v$ male heterosexuals). Ten had been exposed to HDV (the first case in 1980) but only two (who did not admit to intravenous drug use) had chronic HDV infections $(p<0.0005 v$ the rehabilitation centre patients).

Conclusions-Although the HBV carriage rate is very similar in these two populations, chronic HDV infections were mainly confined to intravenous drug users. However, reports from the USA and France indicate spread of delta virus to the male homosexual community and, since there is clearly a pool of HDV in SE London, vaccination against $\mathrm{HBV}$ in these risk groups in likely to be cost-effective and should be actively encouraged.

The risks associated with hepatitis B virus (HBV) infection are compounded by the hepatitis delta virus (HDV), an obligate parasite which requires HBV to produce HBsAg as a coat for hepatitis delta virions. Delta virus infections are particularly associated with intravenous drug users and were considered to be relatively uncommon in homosexual men, but two recent studies from the United States ${ }^{1}$ and France ${ }^{2}$ have reported HDV infections in up to $15 \%$ of HBV carriers among the male homosexual populations in these countries. It is not known whether HDV adversely influences the outcome of acute $\mathrm{HBV}$ infection, but there is no doubt that concurrent HDV infection in chronic HBV carriers is usually associated with liver damage, rapid progression to cirrhosis, and increased mortality. ${ }^{3}$

Although the delta virus has been present in the British intravenous drug using population since at least $1976,{ }^{4}$ a recent study ${ }^{5}$ in our neighbouring areas of Greenwich and Bexley indicated that the virus apparently did not arrive in south east London until 1982, whereupon it spread rapidly through the HBsAg positive intravenous drug using population- $16 \%$ of whom overall had evidence of delta virus infection. ${ }^{5}$

The purpose of the present study was to define the incidence and rates of HBV and HDV infection among intravenous drug users in south east London and to assess the relative risks by comparing these indices with findings in patients attending a sexually transmitted disease clinic in the same area.

\section{Methods}

The study cohort comprised 372 consecutive intravenous drug users ( 278 males, 94 females) admitted to a SE London residential rehabilitation centre over a six year period from January 1983 to December 1988, and 1481 subjects (1319 males, 162 females) seen at a sexually transmitted disease clinic in the same area between July 1979 and December 1986.

Serum samples from each patient were tested initially for hepatitis B surface antigen ( $\mathrm{HBsAg}$ ) and the corresponding antibody (anti-HBs). All HBsAg positive samples were then further tested for hepatitis B " $e$ " antigen ( $\mathrm{HBeAg}$ ) and antibody (anti-HBe), IgM antibody to the HBV "core" antigen (IgM anti-HBc), delta antigen (HDAg), IgM antiHDAg, and total anti-HDAg. In addition, 193 patients who were seropositive for anti-HBs were tested for total anti-HDAg. These 193 comprised all of the anti-HBs positive patients from the sexually transmitted disease clinic who admitted to intravenous drug use and 150 randomly selected anti-HBs positive patients: 50 ( 37 males, 13 females) from among the rehabilitation centre group, and 100 (60 male homosexuals, 27 male and 13 female heterosexuals) from among those sexually transmitted disease clinic patients who did not admit to intravenous drug usage. 
$\mathrm{HBsAg}, \mathrm{HBeAg}$, anti-HBs, anti-HBe, and total anti-HDAg were detected by radioimmunoassay (Abbott Laboratories, Chicago, IL, USA) and IgM anti-HBc by an enzyme immunoassay (Abbott). HDAg and IgM anti-HDAg were detected by enzyme immunoassay (Noctech, Dublin, Eire).

Statistical analyses were performed with the Wilcoxon rank sum test or the $\chi^{2}$ test with Yates' correction, as appropriate.

\section{Results}

INTRAVENOUS DRUG USER REHABILITATION PATIENTS

Of the 372 intravenous drug users screened, 195 $(52.4 \%)$ had evidence of exposure to HBV, of whom 177 were seropositive only for anti-HBs (table I). Of the remaining 18 , one had acute hepatitis B (HBsAg titre 1:400, anti-HBe and IgM anti-HBc positive) and 17 had chronic $\mathrm{HBV}$ infection with $\mathrm{HBsAg}$ titres ranging from 1:8 to $1: 25600$ (median $1: 3200$ )-a carriage rate of $8.7 \%$ among those with serological evidence of

Table I Analysis of screening for hepatitis $B$ virus serological markers in 372 intravenous drug users attending $a$ rehabilitation centre

\begin{tabular}{|c|c|c|c|}
\hline Status & Males & Females & $\begin{array}{l}\text { Total } \\
\left(\begin{array}{c}0 \\
0\end{array}\right)\end{array}$ \\
\hline $\begin{array}{l}\text { At risk } \\
\text { (negative for all markers) }\end{array}$ & 132 & 45 & 177 \\
\hline Immune & 129 & 48 & $\begin{array}{l}177 \\
(47 \cdot 6)\end{array}$ \\
\hline $\begin{array}{l}\text { HBsAg positive } \\
\text { (a) Acute infection } \\
\text { (IgM-anti-HBc positive) }\end{array}$ & 1 & 0 & $\begin{array}{l}1 \\
(0 \cdot 3)\end{array}$ \\
\hline $\begin{array}{l}\text { (b) Chronic infection } \\
\text { (IgM-anti-HBc negative) }\end{array}$ & 16 & 1 & $\begin{array}{l}17 \\
(4 \cdot 6)\end{array}$ \\
\hline Totals & 278 & 94 & 372 \\
\hline
\end{tabular}

Table II Delta virus ( $H D V$ ) markers in 68 of the 195 rehabilitation centre patients who had evidence of exposure to hepatitis $B$ virus ( $H B V)$

\begin{tabular}{|c|c|c|c|c|}
\hline \multirow[b]{2}{*}{ Status } & \multirow[b]{2}{*}{$\begin{array}{l}\text { Number } \\
\text { tested } \\
\text { for HDV } \\
\text { markers }\end{array}$} & \multicolumn{3}{|c|}{ Number seropositive for } \\
\hline & & $\begin{array}{l}\operatorname{Ig} M \\
\text { anti-HDAg } \\
(M / F)\end{array}$ & $\begin{array}{l}\text { Total } \\
\text { Anti-HDAg } \\
(M / F)\end{array}$ & $\begin{array}{l}H D A g \\
(M / F)\end{array}$ \\
\hline $\begin{array}{l}\text { Immune } \\
\text { (anti-HBs positive) }\end{array}$ & 50 & 0 & $3 / 2$ & 0 \\
\hline $\begin{array}{l}\text { Acute } \\
\text { (HBsAg and IgM-anti-HBc positive) }\end{array}$ & 1 & 0 & 0 & 0 \\
\hline $\begin{array}{l}\text { Chronic } \\
\text { (HBsAg positive, IgM-anti-HBc } \\
\text { negative) }\end{array}$ & 17 & $11 / 1$ & $11 / 1$ & 0 \\
\hline Totals & 68 & 12 & 17 & 0 \\
\hline
\end{tabular}

Table III Analysis of 406 subjects attending a sexually transmitted disease clinic who were found to be seropositive for at least one marker of hepatitis $B$

\begin{tabular}{|c|c|c|c|c|}
\hline \multirow[b]{2}{*}{ Status } & \multirow{2}{*}{$\begin{array}{l}\text { Male } \\
\text { homosexuals }\end{array}$} & \multicolumn{2}{|c|}{ Heterosexuals } & \multirow{2}{*}{$\begin{array}{l}\text { Total } \\
\left(\begin{array}{c}0 \\
o\end{array}\right)\end{array}$} \\
\hline & & Males & Females & \\
\hline \multicolumn{5}{|l|}{ IVDU } \\
\hline $\begin{array}{l}\text { Immune } \\
\text { (anti-HBs positive) } \\
\mathrm{HBsAg} \text { positive }\end{array}$ & 8 & 21 & 13 & $\begin{array}{l}42 \\
(10 \cdot 3)\end{array}$ \\
\hline $\begin{array}{l}\text { (a) Acute infection } \\
\text { (IgM anti-HBc positive) }\end{array}$ & 2 & 0 & 0 & \multirow{2}{*}{$\begin{array}{c}2 \\
(0 \cdot 5) \\
2 \\
(0 \cdot 5)\end{array}$} \\
\hline $\begin{array}{l}\text { (b) Chronic infection } \\
\text { (IgM anti-HBc negative) }\end{array}$ & 0 & 1 & 1 & \\
\hline \multicolumn{5}{|l|}{ Non-IVDU } \\
\hline $\begin{array}{l}\text { Immune } \\
\text { (anti-HBs positive) } \\
\text { HBsAg positive }\end{array}$ & 242 & 36 & 30 & $\begin{array}{l}308 \\
(75 \cdot 9)\end{array}$ \\
\hline $\begin{array}{l}\text { (a) Acute infection } \\
\text { (IgM anti-HBc positive) }\end{array}$ & 18 & 1 & 3 & \multirow{2}{*}{$\begin{array}{l}22 \\
(5 \cdot 4) \\
30 \\
(7 \cdot 4)\end{array}$} \\
\hline $\begin{array}{l}\text { (b) Chronic infection } \\
\text { (IgM anti-HBc negative) }\end{array}$ & 22 & 5 & 3 & \\
\hline Totals & 292 & 64 & 50 & 406 \\
\hline
\end{tabular}

exposure to $\mathrm{HBV}$. Four of these 17 were $\mathrm{HBeAg}$ positive, 11 had anti-HBe, and two had neither.

Twelve $\left(70 \cdot 6^{\circ}\right.$ o $)$ of the 17 with chronic $\mathrm{HBV}$ had evidence of concurrent delta virus infection (table II). None had detectable HDAg in serum. HBsAg titres in these 12 were lower than in the five who did not have delta markers (median 1:3200 $v$ $1: 12800$ ) but this difference is not statistically significant $(p>0 \cdot 1)$.

Of the 50 patients randomly selected from the 177 who were positive for anti-HBs, five (three males, two females) were found to be positive for total anti-HDAg but negative for IgM antiHDAg (table II). By extrapolation (and including the 12 with chronic HDV infection), it is estimated that $30\left(15.4^{\circ}{ }_{0}\right)$ of the 195 patients who had serological evidence of exposure to HBV may also have been exposed to HDV.

Six of the cases with HDV markers (including three of the five positive for anti-HBs) were first identified in 1984. The remaining cases were spread evenly over the following years, with three each in 1985, 1986, and 1988, and two in 1987.

SEXUALLY TRANSMITTED DISEASE CLINIC PATIENTS A total of $406(27 \cdot 4 \%)$ of the 1481 sexually transmitted disease clinic patients tested were found to have at least one marker of exposure to HBV. The majority (292) of these were male homosexuals (table III), only 10 of whom admitted to intravenous drug usage. Of the 282 non-intravenous drug using homosexuals, 242 $(85.8 \%)$ were seropositive only for anti-HBs and 40 were $\mathrm{HBsAg}$ positive- 18 with acute and 22 with chronic HBV infections. Fourteen $\left(77 \cdot 8^{\circ}{ }_{0}\right)$ of the 18 with acute $\mathrm{HBV}$ infection were $\mathrm{HBeAg}$ positive, two had anti-HBe, and two had neither, while $15(68.2 \%)$ of the 22 with chronic HBV were $\mathrm{HBeAg}$ positive and seven had anti-HBe. One of these seven also had chronic HDV infection (IgM anti-HDAg positive) and was the only patient among the non-intravenous drug using homosexual group who had any evidence of exposure to delta virus.

Two of the 10 male homosexuals with HBV markers who admitted to intravenous drug use had acute HBV infection, both of whom were positive for IgM anti-HBc and $\mathrm{HBeAg}$. One of these two was also seropositive for HDAg (table IV) and was considered to have acute HDV coinfection. The remaining eight intravenous drug using homosexuals had anti-HBs as the only HBV marker, but one was also positive for total anti-HDAg (table IV). The above findings equate to a carriage rate of $7 \cdot 5^{\circ} \mathrm{o}$ among the male homosexuals who had been exposed to HBV.

Of the 114 hetrosexuals who had HBV markers, 36 were intravenous drug users ( 22 male) and 78 (42 male) did not admit to intravenous drug use (table III). Among the latter, 66 had anti-HBs as the only HBV marker (table III) and 12 were HBsAg positive. Four of these 12 had acute HBV infection-two (both female) being $\mathrm{HBeAg}$ positive and two (one male) having anti-HBe. The remaining eight had chronic HBV, of whom two (both male) were $\mathrm{HBeAg}$ positive and six (three males) had anti-HBe-one of the males also having chronic HDV infection (table IV).

Thirty (19 male) of the 36 heterosexual intravenous drug users with HBV markers had 
anti-HBs only (table III). Four others (two male) were seropositive for anti-HBs and total antiHDAg (table IV). The remaining two patients (one male) had chronic HBV infection. Both of these were anti-HBe positive and neither had evidence of exposure to delta virus. The overall carriage rate among male heterosexuals with HBV markers was thus $9.4 \%$, which is not significantly different $(p>0.8)$ from that in the male homosexual group.

Two of the further 100 anti-HBs positive non-intravenous drug users tested for delta virus markers were seropositive for total anti-HDAg. Both were male heterosexuals and were negative for IgM anti-HDAg (table IV). By extrapolation (and including the $\mathrm{HBsAg}$ positive cases) it is estimated that $15(3.7 \%)$ of the 406 patients who had been exposed to HBV may also have been exposed to HDV-a much lower frequency $(p<0.0005)$ than in the rehabilitation centre patients.

Overall, therefore, $10(5 \%)$ of the 199 sexually transmitted disease clinic patients with HBV markers who were tested had serological evidence of exposure to HDV (table IV). All were United Kingdom born Caucasians and none had concomitant HIV infection. Six (two homosexual) were from among the 48 who admitted to intravenous drug use-a frequency $(12.5 \%)$ which, although higher, is not significantly different $(p>0.2)$ from that $(6.2 \%)$ among the rehabilitation centre patients. It is noteworthy, however, that only two $(6.3 \%)$ of the 32 sexually transmitted disease clinic patients who were HBV carriers had chronic HDV infection and that neither of these admitted to intravenous drug use. This contrasts with the 12 of 17 rehabilitation centre HBV carriers who had chronic HDV infection $(\mathrm{p}<0.0005)$.

Three male intravenous drug users attending the sexually transmitted disease clinic were identified as having previous exposure to delta virus (seropositive for anti-HBs and total antiHDAg) prior to 1982-one (heterosexual) in 1980 and two (one homosexual) in 1981. The remaining cases with delta markers were distributed over the succeeding years-the patient with acute HDV (table IV) presenting in 1983 and the two with chronic infection in 1985. None of the patients tested in 1986 had any delta virus markers.

\section{Discussion}

The present findings suggest that the delta virus may have been present among the south east London intravenous drug using population somewhat earlier than was thought, ${ }^{5}$ three cases of previous exposure to HDV having been identified among intravenous drug users attending the sexually transmitted disease clinic in 1980/81. In all, 23 of the intravenous drug user cases were $\mathrm{HBsAg}$ positive (five sexually transmitted disease clinic patients and 18 from the rehabilitation centre) and 13 of these $\left(56.5^{\circ} \%\right)$ had at least one marker of HDV infection. This is a much higher incidence than that previously reported for the neighbouring areas of south east London, ${ }^{5}$ and was accounted for almost entirely by the very high $\left(70 \cdot 6^{\circ}\right)$ prevalence of chronic HDV infection among the rehabilitation centre patients with chronic hepatitis B.

There was no significant overall difference in the incidence of HDV serum markers in intravenous drug users with HBV markers attending the two centres; therefore the apparent exclusivity of chronic HDV to intravenous drug users attending the rehabilitation centre cannot have been due to different rates of exposure to the virus, but it is possible that there may have been inadvertent bias in patient selection. Participation in the rehabilitation scheme is voluntary and, because of their underlying liver disease, subjects with chronic HDV infection might have been more motivated to attend the centre. This seems unlikely, however, because $97 \%$ of the patients at the centre did not have any HDV serum markers.

The present study does not confirm recent reports of a high frequency of exposure to delta virus among non-intravenous drug using male homosexuals. ${ }^{12}$ Indeed, only one $(0.35 \%)$ of the 282 homosexuals with evidence of HBV exposure studied here who did not admit to intravenous drug use had any serum marker of HDV. However, it is clear from these previous reports that the virus can spread into the homosexual population (presumably via homosexual intravenous drug users). Nearly half of the rehabilitation centre patients and about $60 \%$ of the male homosexuals attending the sexually transmitted disease clinic did not have serological evidence of exposure to HBV. Although this might be a slight overestimate (because patients were not tested for IgG anti-

Table IV Delta virus serum markers in patients attending the sexually transmitted disease clinic with evidence of exposure to hepatitis $B$ virus ( $H B V$ )

\begin{tabular}{|c|c|c|c|c|c|c|c|c|c|}
\hline \multirow[b]{2}{*}{ Status } & \multirow{2}{*}{$\begin{array}{l}\text { Total } \\
\text { with HBV } \\
\text { markers }\end{array}$} & \multirow{2}{*}{$\begin{array}{l}\text { Number } \\
\text { tested } \\
\text { for HDV } \\
\text { markers }\end{array}$} & \multicolumn{3}{|c|}{$\begin{array}{l}\text { Male homosexuals, } \\
\text { number positive for }\end{array}$} & \multicolumn{3}{|c|}{$\begin{array}{l}\text { Heterosexuals }(M / F) \text {, } \\
\text { number positive for }\end{array}$} & \multirow{2}{*}{$\begin{array}{l}\text { Total } \\
\text { positive } \\
\text { for any } \\
\text { HDV } \\
\text { marker }\end{array}$} \\
\hline & & & $H D A g$ & $\begin{array}{l}\operatorname{IgM} \\
a-H D A g\end{array}$ & $\begin{array}{l}\text { Total } \\
a-H D A g\end{array}$ & $H D A g$ & $\begin{array}{l}I g M \\
a-H D A g\end{array}$ & $\begin{array}{l}\text { Total } \\
a-H D A g\end{array}$ & \\
\hline \multirow{3}{*}{$\begin{array}{l}\text { IVDU } \\
\text { Immune } \\
\text { (anti-HBs positive) } \\
\text { HBsAg positive } \\
\text { (a) Acute infection } \\
\text { (b) Chronic infection } \\
\text { (IgM anti-HBc negative) }\end{array}$} & 43 & 43 & 0 & 0 & 1 & 0 & 0 & $2 / 2$ & 5 \\
\hline & 3 & 3 & 1 & 0 & 0 & 0 & 0 & 0 & 1 \\
\hline & 2 & 2 & 0 & 0 & 0 & 0 & 0 & 0 & 0 \\
\hline $\begin{array}{l}\text { Non-IVDU } \\
\text { Immune } \\
\text { (anti-HBs positive) } \\
\text { HBsAg positive }\end{array}$ & 307 & 100 & 0 & 0 & 0 & 0 & 0 & $2 / 0$ & 2 \\
\hline $\begin{array}{l}\text { HBsAg positive } \\
\text { (a) Acute infection } \\
\text { (IgM anti-HBc positive) }\end{array}$ & 21 & 21 & 0 & 0 & 0 & 0 & 0 & 0 & 0 \\
\hline $\begin{array}{l}\text { (b) Chronic infection } \\
\text { (IgM anti-HBc negative) }\end{array}$ & 30 & 30 & 0 & 1 & 1 & 0 & $1 / 0$ & $1 / 0$ & 2 \\
\hline Totals & 406 & 199 & & & & & & & 10 \\
\hline
\end{tabular}


$\mathrm{HBc}$ ), it is obvious that there are large numbers of individuals in these two populations who are at very high risk of acquiring $\mathrm{HBV}$, and thus also $\mathrm{HDV}$, infections.

Vaccination against hepatitis B has been widely available in the SE London area since 1986 but even today few of these individuals have received the vaccine. It is uncertain whether this is because of the cost involved or due to lack of awareness of the magnitude of the problem but, since there is apparently a pool of delta virus among intravenous drug users in the area and in view of the high cost in terms of morbidity and treatment of patients with HDV related liver disease, an active programme of vaccination against $\mathrm{HBV}$ in both the homosexual and intravenous drug using populations would seem desirable. It is recognised that HIV infection reduces the response to HBV vaccines and we are currently investigating the nature and extent of this hyporesponsiveness. However, the most recent data suggest that less than $5 \%$ of the London intravenous drug using population are currently infected with $\mathrm{HIV}^{6}$ which is a very small proportion of the total at risk. The cost-effectivness of such a programme could be markedly increased by vaccinating those at risk as early as possible ${ }^{6}$ and by screening individuals for $\mathrm{HBsAg}$ and anti-HBs prior to vaccination to ensure that only those who had not been previously exposed to $\mathrm{HBV}$ received the vaccine.

Solomon RE, Kaslow RA. Phair JP, et al. Human immunodeficiency virus and hepatitis delta virus in homosexual men. Ann Intern Med 1988; 108: 51-4.

2 Pol S, Dubois F, Roingeard P, et al. Hepatitis delta virus infection in French male HBsAg-positive homosexuals. Hepatology 1989; 10: 342-5.

3 Rizetto M, Bonino F, Verme G. Hepatitis delta virus infection of the liver: progress in virology, pathobiology and diagnosis. Semin Liver Dis 1988; 8: $350-6$.

4 Ponzetto A, Cohen BJ, Vandervelde EM, Mortimer PP. Delta agent in Britain. Lancet 1983; ii: 1145-6.

5 Kelly V, Kensit J, Barrett A. Hepatitis (delta) infection in South-East London. Lancet 1989; i: 45 (letter).

6 Hart GJ, Woodward N, Johnson AN, Tighe J, Parry JV Hart GJ, Woodward N, Johnson AN, Tighe J, Parry JV,
Adler MW. Prevalence of HIV, hepatitis B and associated Adler MW. Prevalence of HIV, hepatitis B and associated
risk behaviour in clients of a needle exchange in central risk behaviour in clients of a
London. Aids 1991; 5: 543-7. 